Article

SILVA, M.R.M. ${ }^{*}$

COSTA, E.A. ${ }^{1}$

CORREAA, M.J.P. ${ }^{1}$

RODRIGUES, A.A.C. ${ }^{1}$

MESQUITA, M.L.R. ${ }^{1}$

\section{Floristic and Phytosociology of WeEds IN UPLAND RICE IN THE HUMID TROPICS}

\author{
Florística e Fitossociologia de Plantas Daninhas na Cultura do Arroz de Terras \\ Altas no Trópico Úmido
}

ABSTRACT - Knowledge of the floristic composition and vegetation structure are essential conditions for development of more efficient and economic weed management strategies in crops in the humid tropics. The objective of the research was to carry on floristic and phytosociological surveys to know the main weeds in upland rice fields in the humid tropics of the Brazilian State of Maranhão. Weed samples were done by means of an open metal rectangle of $0.15 \mathrm{~m}^{2}$ thrown at random in the vegetative and reproductive stages of rice crop in 2009/10 and 2010/2011 harvest. A total of 65 species from 23 families was identified 35 (53.85\%) from the eudicotyledons botanical group, 29 (44.06\%) from the monocotyledonous and one $(1.53 \%)$ belonged to the pteridophytes. The most representative families were from the monocotyledonous botanical group including Poaceae and Cyperaceae, followed by Amaranthaceae and Malvaceae, both from the eudicotyledons group. The weed species with higher importance values in the upland rice crop vegetative stage were Urochloa sp., Panicum sp., C. flavus, C. benghalensis and C. argutus whereas in the reproductive stage the higher importance values were recorded for $S$. latifolia, C. argutus, L. octovalvis, A. tenella and P. maximum. The most important weeds in the crop vegetative phase were mainly from the monocotyledonous group, while in reproductive one they were the eudicotyledons. Weed diversity was high and the floristic similarity was lower in the vegetative one compared to the reproductive stage of upland rice cultivation in the humid tropics.

Keywords: Oryza sativa, weed community, phytosociology.

RESUMO - O conhecimento da composição florística e da estrutura fitossociológica é condição essencial para definição de estratégias mais eficientes e econômicas de manejo da comunidade infestante em culturas agrícolas no trópico úmido. $O$ objetivo desta pesquisa foi realizar levantamento florístico e fitossociológico para conhecimento das principais plantas daninhas na cultura do arroz de terras altas no trópico úmido do Estado do Maranhão. As coletas das plantas foram obtidas pelo lançamento aleatório de um retângulo vazado de $0,15 \mathrm{~m}^{2}$ nas fases vegetativa e reprodutiva da cultura do arroz, nas safras de 2009/2010 e 2010/2011. Foram identificadas 65 espécies distribuídas em 22 famílias, sendo 35 eudicotiledôneas, 29 monocotiledôneas e 1 pteridófita. As famílias mais representativas foram Poaceae e Cyperaceae, seguidas por Amaranthaceae e Malvaceae. Na fase vegetativa da cultura, as plantas daninhas de maior valor de importância foram Urochloa sp., Panicum sp., Cyperus flavus, Commelina benghalensis e Corchorus argutus. Na fase reprodutiva, predominaram Spermacoce latifolia, Corchorus argutus, Ludwigia octovalvis, Alternanthera tenella e Panicum maximum. As plantas daninhas da classe das monocotiledôneas destacaram-se na fase vegetativa

Planta Daninha 2017; v35:e017164304

1 Universidade Estadual do Maranhão - UEMA, São Luís-MA, Brasil. 
da cultura, enquanto na reprodutiva foram as eudicotiledôneas. A diversidade de plantas daninhas foi elevada, e a similaridade florística foi menor na fase vegetativa, comparada à reprodutiva, da cultura do arroz de terras altas no trópico úmido.

Palavras-chave: Oryza sativa, comunidade infestante, levantamento florístico.

\section{INTRODUCTION}

Rice (Oryza sativa) is an important food culture in Brazil, mainly in the state of Maranhão, where it is accounted for many family farmers' food security. According to Conab (2015), in the 2014/2015 harvest Brazil's production reached 12,448.6 thousand tons, the Northeast region produced 694.7 thousand tons and Maranhão was the main rice producer in this region, with 496 thousand tons $(71.4 \%)$.

Although the state of Maranhão is located in the Northeastern area, it presents transitional climatic characteristics between this region (semi-arid) and the Amazon (humid), with high rainfall during the rainy season and high and uniform temperatures throughout the year. These conditions result in edaphoclimatic characteristics that allow the cultivation of rice in practically the whole state.

In Maranhão, rice is grown under three production systems, with predominance of upland cultivation (cutting and burning system), followed by wet and irrigated floodplains. The cutting and burning system is based on the shallow cutting of secondary vegetation (capoeira), followed by burning and subsequent cultivation of rice in monoculture or intercropped with maize, beans and cassava for two or three years and leaving the area for fallow (Marques et al., 2011).

The upland system stands out mainly in the Brazilian micro-region of Pindaré, where it has great socioeconomic importance and family farmers are mainly responsible for the production. And weeds are among the difficulties faced for rice cultivation.

Weeds in the Brazilian micro-region of Pindare are highly favored by climatic conditions, which in the humid tropics are favored in their rapid development and changes in a short period of time, which results in reduction of productivity of upland rice cultivation due to competition for light, space and soil nutrients. Research conducted by Silva et al. (2015) for two years in the humid tropics have shown that weed coexistence throughout the upland rice cultivation cycle has reduced production in $83.4 \%$ and $72 \%$.

Knowledge about the most damaging weed populations an agricultural crops is of great relevance to reduce yield losses and to adjust the management system. This knowledge is usually obtained through phytosociological surveys involving indices of relative density, relative frequency, relative dominance and relative importance. Pitelli (2000) points out that species harmed by agricultural practices tend to decrease their relative importance, while indifferent or favored species tend to increase it. Analysis of the most affected component (density, frequency or dominance) can provide important evidence of how the environmental pressure agent acts against impaired populations.

Marques et al. (2011), in a phytosociological survey in the humid tropics, have verified that there was a change in the classes and families dominance due to preparation of the soil with the selection of species of difficult control in the cutting and burning system. Therefore, knowledge about the floristic composition and phytosociological structure of weeds in an agricultural crop is an essential condition for the definition of more appropriate management strategies, particularly in regions of the humid tropics, where dynamics of growth and occupation of agroecosystems are very rapid.

In view of the above, this research has aimed to carry out a floristic and phytosociological survey for knowledge about the main weeds in upland rice cultivation in the humid tropics of the Brazilian state of Maranhão. 


\section{MATERIALS AND METHODS}

The research was done in an area of family farmers in the Brazilian municipalities of Buriticupu (4'20'34" of south latitude and $46^{\circ} 24^{\prime} 6^{\prime \prime}$ of west longitude) and Alto Alegre do Pindaré $\left(4^{\circ} 04^{\prime} 08^{\prime \prime}\right.$ of south latitude and $45^{\circ} 41^{\prime} 24^{\prime \prime}$ of west longitude) located in the Pindaré micro-region of the state of Maranhão, during the rainy season of 2009/2010 and 2010/2011 harvests, respectively. The climate in the municipalities, according to Thorntwaite climate classification system, is type $\mathrm{B}_{1}$ WA'a', type B1 humid climate, with moderate water deficiency in the winter between the months of June and September, megathermal, that is, average monthly temperature always higher than $18{ }^{\circ} \mathrm{C}$. Rainfall totals range from 1,200 to $2,000 \mathrm{~mm}$ and annual air relative humidity is over $82 \%$ (GEPLAN, 2002). Predominant soils of these municipalities are classified as Red-Yellow Acrisol and Yellow Latosol (Santos et al., 2013).

Surveys were carried out in four areas of each municipality. In the municipality of Buriticupu they were identified by B1, B2, B3 and B4 and B1 and B3 measured approximately 0.5 ha while B2 and B4 measured 1 ha. In the municipality of Alto Alegre do Pindaré, areas were approximately 1 ha and were called P1, P2, P3 and P4, the latter being subject to periodic flooding. The predominant cultivation system in the two municipalities was cutting and burning the vegetation, except the P1 area, where soil preparation would be by the conventional method.

The collections of botanical material were carried out by randomly launching a $0.50 \mathrm{~m} \times 0.30 \mathrm{~m}$ hollow rectangle 30 times to areas B2 and B4 and 20 times to areas B1 and B3 during each of the crop vegetative and reproductive phases, totaling $30 \mathrm{~m}^{2}$. For the Brazilian municipality of Alto Alegre do Pindaré, this rectangle was launched 30 times in each area in the two phases evaluated, making a total of $36 \mathrm{~m}^{2}$.

At each launch, the plants shoots were cut close to the ground and packed in bags for identification and counting of individuals by species. Weed identifications were performed through examining the material and consulting the relevant literature. Samples were then placed in a greenhouse with forced air ventilation at $65^{\circ} \mathrm{C}$ for dry matter quantification.

The weed community density and dry matter were expressed in number of plants and grams of dry matter per square meter, respectively. These data for each population were used to determine phytosociological parameters: relative density (ReDe), relative frequency $(\mathrm{ReFr})$, relative dominance (ReDo) and importance value index (IVI) (Müller-Dombois and Ellemberg, 1974).

In addition to the phytosociological parameters, the Jaccard similarity index with dendrogram development and the Shannon's diversity index ( $\left.\mathrm{H}^{\prime}\right)$ were also calculated. Jaccard similarity index was determined between the vegetative and reproductive phases and between the municipalities. According to Pinto Coelho (2000), it is one of the most simple and used indexes, being defined by the formula:

$$
j=\frac{a}{a+b+c}
$$

where: $a=$ Number of species present only in sample $a ; b=$ Number of species present only in sample $b$; and $c=$ Number of species common to both samples.

The dendrogram was constructed based on the Unweighted Pair Group Method with Arithmetic Mean (UPGMA), in which grouping was performed from the arithmetic mean of its elements using the FITOPAC software (Shepherd, 1994).

Shannon's diversity index (H') (Magurran, 1988) quantifies the species diversity of a system considering its richness and uniformity and was obtained by formula:

$$
H^{\prime}=-\sum_{I=1}^{S} p i \ln p i
$$

where: $\ln =$ Napierian logarithm; $p i=n i / \mathrm{N} ; n i=$ Number of individuals sampled from the species $i$; and $\mathrm{N}=$ Total number of individuals sampled. 


\section{RESULTS AND DISCUSSION}

There were 65 species distributed in 22 families, of which 35 (53.85\%) were eudicotyledonous, 29 (44.06\%) were monocotyledonous and 1 (1.53\%) was pteridophyte. The municipality of Buriticupu presented 14 families and 26 species. And Alto Alegre do Pindaré presented 18 families and 51 species (Table 1). Such results suggest that weed species diversity was high in upland rice cultivation under humid tropic conditions. Studies conducted by Silva et al. (2015) with upland rice in the same climatic conditions corroborate the results obtained for the high diversity of species found, since they have found 52 species distributed in 18 families.

Table 1 - Floristic survey of weeds identified in vegetative and reproductive phases of upland rice cultivation in the Brazilian municipalities of Buriticupu and Alto Alegre do Pindaré, in the 2009/2010 and 2010/2011 harvests, respectively

\begin{tabular}{|c|c|c|c|}
\hline Families & Species & Vegetative phase & Reproductive phase \\
\hline \multicolumn{4}{|c|}{ Brazilian municipality of Buriticupu } \\
\hline \multirow{3}{*}{ Amaranthaceae } & Alternanthera brasiliana (L.) Kuntze. & & $\mathrm{X}$ \\
\hline & Alternanthera tenella Colla. & $\mathrm{X}$ & $\mathrm{X}$ \\
\hline & Amaranthus deflexus L. & $\mathrm{X}$ & \\
\hline \multirow{4}{*}{ Asteraceae } & Acanthospermum hispidum DC. & $\mathrm{X}$ & \\
\hline & Bidens pilosa L. & $\mathrm{X}$ & $\mathrm{X}$ \\
\hline & Emilia coccinea (Sims) G. Don. & & $\mathrm{X}$ \\
\hline & Erechtites hieraciifolius (L.) Raf. & & $\mathrm{X}$ \\
\hline Cleomaceae & Cleome affinis DC. & $\mathrm{X}$ & \\
\hline \multirow{2}{*}{ Commelinaceae } & Commelina erecta $\mathrm{L}$. & & $\mathrm{X}$ \\
\hline & Commelina benghalensis L. & $\mathrm{X}$ & $\mathrm{X}$ \\
\hline Convolvulaceae & Ipomoea sp. & $\mathrm{X}$ & $\mathrm{X}$ \\
\hline Cucurbitaceae & Momordica charantia L. & $\mathrm{X}$ & \\
\hline \multirow{2}{*}{ Euphorbiaceae } & Croton lobatus L. & $\mathrm{X}$ & $\mathrm{X}$ \\
\hline & Euphorbia heterophylla $\mathrm{L}$ & & $\mathrm{X}$ \\
\hline Lamiaceae & Marsypianthes chamaedrys (Vahl) Kuntze. & & $\mathrm{X}$ \\
\hline Loganiaceae & Spigelia anthelmia $\mathrm{L}$. & $\mathrm{X}$ & $\mathrm{X}$ \\
\hline Malvaceae & Corchorus argutus Kurt. & $\mathrm{X}$ & $\mathrm{X}$ \\
\hline \multirow{5}{*}{ Poaceae } & Urochloa sp. & $\mathrm{X}$ & \\
\hline & Imperata brasiliensis sp. & $\mathrm{X}$ & \\
\hline & Melinis minutiflora P. Beauv. & & $\mathrm{X}$ \\
\hline & Pariana sp. & & $\mathrm{X}$ \\
\hline & Paspalum paniculatum $\mathrm{L}$. & $\mathrm{X}$ & \\
\hline Schizaeceae & Lygodium venustum $\mathrm{SW}$. & $\mathrm{X}$ & $\mathrm{X}$ \\
\hline \multirow{2}{*}{ Solanaceae } & Solanum lycocarpum St. Hil & $\mathrm{X}$ & $\mathrm{X}$ \\
\hline & Solanum americanum Mill & & $\mathrm{X}$ \\
\hline Verbenaceae & Lantana camara L. & $\mathrm{X}$ & $\mathrm{X}$ \\
\hline \multicolumn{4}{|c|}{ Brazilian municipality of Alto Alegre do Pindaré } \\
\hline Amaranthaceae & Alternanthera tenella Colla. & $\mathrm{X}$ & $\mathrm{X}$ \\
\hline \multirow{3}{*}{ Asteraceae } & Siegesbckia orientalis L. & $\mathrm{X}$ & \\
\hline & Melapodium divaricatium (Rich) DC. & $\mathrm{X}$ & \\
\hline & Gnaphalium coarctutum Willd. & & $\mathrm{X}$ \\
\hline Cleomaceae & Cleome affinis DC. & & $\mathrm{X}$ \\
\hline \multirow{3}{*}{ Commelinaceae } & Commelina erecta $\mathrm{L}$. & $\mathrm{X}$ & \\
\hline & Commelina benghalensis L. & $X$ & $X$ \\
\hline & Murdannia nudiflora (L.) Brenan & $\mathrm{X}$ & $\mathrm{X}$ \\
\hline Convolvulaceae & Ipomoea sp. & $\mathrm{X}$ & \\
\hline
\end{tabular}


Table 1, cont.

\begin{tabular}{|c|c|c|c|}
\hline \multicolumn{4}{|c|}{ Brazilian municipality of Alto Alegre do Pindaré } \\
\hline Families & Species & Vegetative phase & Reproductive phase \\
\hline \multirow{9}{*}{ Cyperaceae } & Cyperus sp. & $\mathrm{X}$ & $\mathrm{X}$ \\
\hline & Cyperus difformis $\mathrm{L}$. & $\mathrm{X}$ & \\
\hline & Cyperus esculentus $\mathrm{L}$. & $\mathrm{X}$ & $\mathrm{X}$ \\
\hline & Cyperus flavus (Vahl) Nees. & $\mathrm{X}$ & $\mathrm{X}$ \\
\hline & Cyperus iria $\mathrm{L}$. & $\mathrm{X}$ & $\mathrm{X}$ \\
\hline & Cyperus lanceolatus Poir. & $\mathrm{X}$ & \\
\hline & Fimbristylis dichotoma (L.) Vahl & $\mathrm{X}$ & $\mathrm{X}$ \\
\hline & Fimbristylis miliaceae (L.) Vahl. & $\mathrm{X}$ & \\
\hline & Pycreus polystachyos (Rottb.) P. Beauv. & & $\mathrm{X}$ \\
\hline \multirow{2}{*}{ Fabaceae } & Aeschynomene denticulada Rudd. & $\mathrm{X}$ & $\mathrm{X}$ \\
\hline & Indigofera hirsuta $\mathrm{L}$. & & $\mathrm{X}$ \\
\hline \multirow{5}{*}{ Malvaceae } & Corchorus argutus Kurt. & $\mathrm{X}$ & $\mathrm{X}$ \\
\hline & Melochia pyramidata $\mathrm{L}$. & & $\mathrm{X}$ \\
\hline & Pavonia cancellata (L.) Cav. & $\mathrm{X}$ & $\mathrm{X}$ \\
\hline & Sida rhombifolia $\mathrm{L}$. & $\mathrm{X}$ & \\
\hline & Sida sp. & $\mathrm{X}$ & $\mathrm{X}$ \\
\hline Melastomataceae & Pterolepis trichotoma (Rottb.) Cogn. & $\mathrm{X}$ & \\
\hline Molluginaceae & Mollugo verticillata $\mathrm{L}$. & $\mathrm{X}$ & $\mathrm{X}$ \\
\hline Onagraceae & Ludwigia octovalvis (Jacq.) P. H. Raven & $\mathrm{X}$ & $\mathrm{X}$ \\
\hline \multirow{15}{*}{ Poaceae } & Urochloa sp. & $\mathrm{X}$ & $\mathrm{X}$ \\
\hline & Urochloa decumbens (Stapf.) R.D. Webster & & $\mathrm{X}$ \\
\hline & Cynodon dactylon (L.) Pers. & $\mathrm{X}$ & \\
\hline & Coix lacryma Jobi L. & $\mathrm{X}$ & \\
\hline & Digitaria sanguinalis (L.) Link. & $\mathrm{X}$ & \\
\hline & Digitaria bicornis (LAM.) Roem. \& Schult. & & $\mathrm{X}$ \\
\hline & Digitaria sp. & $\mathrm{X}$ & \\
\hline & Echinochloa colona (L.) Pers. & $\mathrm{X}$ & \\
\hline & Eleusine indica (L.) Gaertn. & $\mathrm{X}$ & \\
\hline & Panicum maximum Jacq. & $\mathrm{X}$ & \\
\hline & Panicum repens L. & $\mathrm{X}$ & $\mathrm{X}$ \\
\hline & Panicum sp. & $\mathrm{X}$ & \\
\hline & Pariana sp. & $\mathrm{X}$ & \\
\hline & Paspalum paniculatum $\mathrm{L}$. & $\mathrm{X}$ & \\
\hline & Paspalum sp. & $\mathrm{X}$ & \\
\hline Plantaginaceae & Micranthemum umbrosum (Walter ex J.F. Gmel) Blake & & $\mathrm{X}$ \\
\hline Phyllantaceae & Phyllanthus niruri L. & $\mathrm{X}$ & \\
\hline \multirow{3}{*}{ Rubiaceae } & Spermacoce latifolia Aubl. & $\mathrm{X}$ & $\mathrm{X}$ \\
\hline & Spermacoce suaveolens (G. Mey) Kuntze. & & $\mathrm{X}$ \\
\hline & Spermacoce verticilata $\mathrm{L}$. & & \\
\hline Schizaeceae & Lygodium venustum SW. & $\mathrm{X}$ & $\mathrm{X}$ \\
\hline Solanaceae & Physalis angulata $\mathrm{L}$. & $\mathrm{X}$ & \\
\hline Verbenaceae & Priva sp. & & $\mathrm{X}$ \\
\hline
\end{tabular}

Comparing the two municipalities, it was verified that nine species and ten weed families were common to both, with Poaceae family standing out, with 5 and 15 species in the Brazilian municipalities of Buriticupu and Alto Alegre do Pindaré, respectively (Table 1). The Poaceae family was represented by many species of fast initial growth and accumulation of biomass, which produce dense soil cover, which causes competition with the crop mainly by the nutrients of the soil and, consequently, reduces the production of upland rice cultivation. This family was 
also identified among the most important ones in upland rice cultivation in several surveys (Cobucci et al., 2001; Silva and Durigan, 2006, 2009; Touré et al., 2013; Mesquita et al.,2013; Silva et al., 2014, 2015).

Another family of relevant importance in upland rice cultivation was Cyperaceae, with nine species, but it only occurred in the municipality of Alto Alegre do Pindaré (Table 1). This result is consistent with that obtained by Silva et al. (2014) when studying a weed seed bank in rice crops in the municipality mentioned, where the Cyperaceae family also presented great diversity of species. Mesquita et al. (2013), also in a rice bank seed study in the central region of the state of Maranhão, have identified this family with great species richness. Touré et al. (2013) have verified the importance of this family in rice cultivation in northern Guinea.

The families of the botanical class of eudicotyledonous that occurred with greater number of species were Amaranthaceae and Malvaceae, with five species each, in Buriticupu and Alto Alegre do Pindaré, respectively (Table 1). These families were also reported by Silva and Durigan (2009) in a study of weed interference in upland rice cultivation.

In the Buriticupu municipality, it was verified that in the vegetative phase of the rice crop the weeds with the highest importance value index (IVI) in the weed community were C. benghalensis, with $86.17 \%$ in area B1; Urochloa sp., with $110.65 \%$ in area B2; Urochloa sp. and C. argutus, with $99.24 \%$ and $95.28 \%$ in area B3; and Panicum sp., with $107.3 \%$ in area B4 (Figure 1A). Most of these species are of the monocotyledonous class, the same botanical class as rice, and are characterized as being very competitive in agricultural crops. Cobucci et al. (2001) have reported that the most aggressive weed species in upland rice grown in the Brazilian Cerrado belong to the genera Brachiaria, Cenchrus, Digitaria, Commelina and Ipomoea.

The species $C$. benghalensis, besides showing a high IVI in the B1 area, was shown to be constant in the other areas, mainly due to the high values of relative dominance (Figure 1A). It is a species whose genus causes economic damage to crops caused by competition for nutrients, water and light, which can make it difficult to harvest grains due to the high water content in the stem and also to hosting insects that hinder the crop full development (Penckowski and Rocha, 2006). Silva et al. (2013), in upland rice cultivation, have also identified this species among the most relevant ones of a weed community, especially in the vegetative phase.

Plants of the genus Urochloa obtained the highest IVI of all areas, mainly in area B2, whose relative density $(\operatorname{ReDe}=61.36 \%)$ was the phytosociological parameter that increased the IVI (Figure 1A). This genus presents generally fast growing plants, with intense tillering, which, by
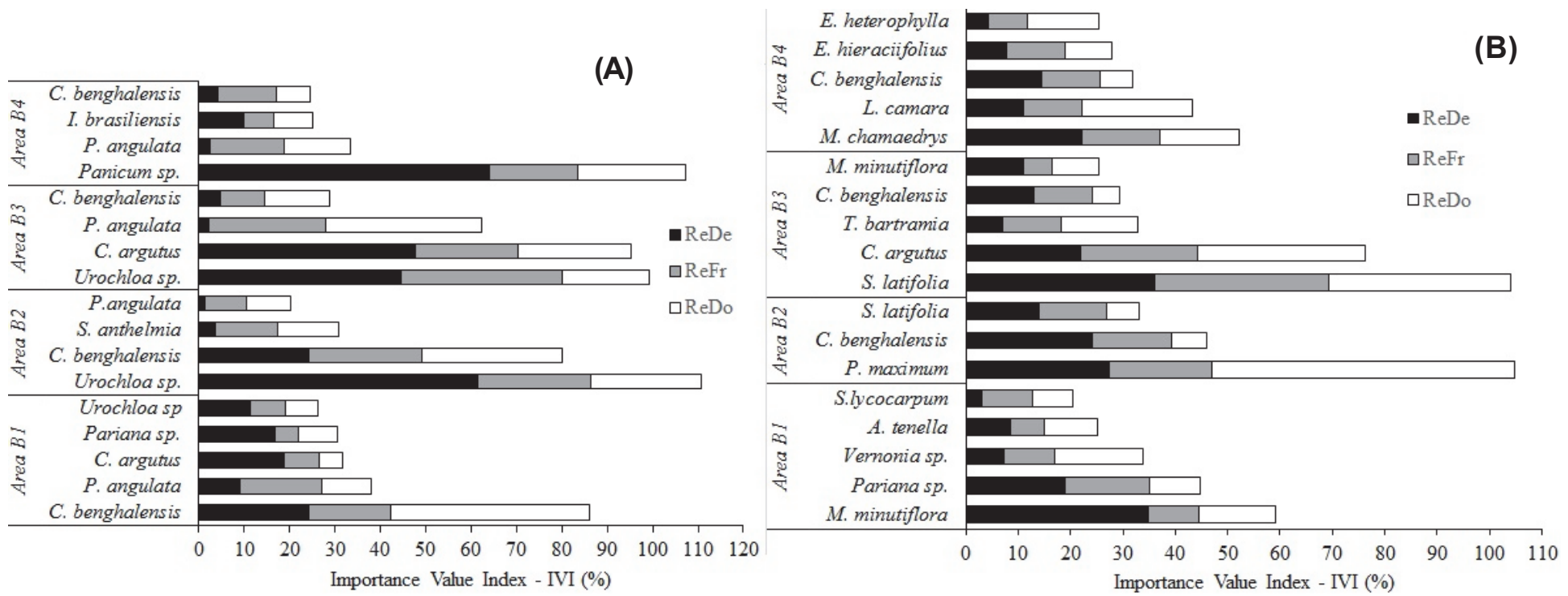

Figure 1 - Phytosociological parameters of the main weeds in (A) vegetative and (B) reproductive phases of upland rice cultivation in the Brazilian municipality of Buriticupu, MA. 2009/2010. 
the evaluation method, very much emphasizes the individual numerical participation, since each tiller is considered an individual. Among the species of this genus, Cobucci et al. (2001) highlight, among the most important ones in upland rice cultivation, Brachiaria decumbens, a perennial plant that reproduces by seed and in a vegetative form, where seed germination is very irregular, as it presents initial dormancy, which makes it difficult to control. Silva and Durigan (2009) have detected B. decumbens as the most competitive species at the time of upland rice harvest in the first agricultural year evaluated. Thus, species of this genus can be considered very harmful to upland rice cultivation for family farmers in the Brazilian micro-region of Pindaré.

Plants of the genus Panicum that presented the second highest IVI in the vegetative phase of rice cultivation in Buriticupu also had greater influence from the relative density ( $\operatorname{ReDe}=64.07 \%$ ) (Figure 1A). Plants of this genus represent weeds that are very damaging to the rice production system in the humid tropics because they present great foliar mass, hindering the development and the harvest. This indicates that management should also be directed to these plants. A study conducted by Mesquita et al. (2013) with weed seed bank in situ and ex situ in an area cultivated with upland rice in the humid tropics has found species of the genus Panicum as important in the study area.

Among the important species of the cultivation vegetative phase of eudicotyledons class, C. argutus stands out, whose relative density $(\mathrm{ReDe}=47.88 \%)$ obtained a high percentage (Figure 1A). It is a sub-woody, very branched plant species, common in annual crops under the cutting and burning system of secondary vegetation, mainly after the first year of cultivation.

In the reproductive phase of the rice crop in the municipality of Buriticupu, some change occurred in the dominance of the species in the weed community in all the areas, whose highest importance values were obtained by the species S. latifolia (IVI $=104.13 \%$ ) in area B3 and P. maximum (IVI $=99.56 \%$ ) in area B2 (Figure $1 \mathrm{~B})$. The change in the dominance of the species was probably a consequence of weeding performed after harvesting in the vegetative phase that acted to select the species most adapted to the cutting and burning system.

In relation to $S$. latifolia, which was the species of highest IVI of all the areas in the crop reproductive phase, it was observed that its density and relative frequency also had the highest values: 36 and $33.3 \%$, respectively (Figure 1B). This suggests that it was a species that spread as a result of weeding in the crop vegetative phase. Silva et al. (2013), in a phytosociological survey in upland rice cultivation, have also identified it among the species of higher IVI in the crop reproductive phase. Results obtained by Terra et al. (2012) have found its presence at the end of the reproductive cycle of flooded farming agriculture rice.

The species $P$. maximum had relative dominance as the greatest influence on its IVI, with value of $57.8 \%$ (Figure 1B). This greater accumulation of biomass is related to its high size and the large amount of foliar mass. Kuva et al. (2003) emphasize that these species, due to the size that they reach, even in low densities, can cause great damages, either by interference or enrichment of the seed bank. Mesquita et al. (2014), studying seed bank in an agricultural area in the cutting and burning system, have verified that this species has shown great adaptation capacity in all places evaluated.

The species C. argutus has also obtained some high IVI $(76.29 \%)$ in area B3, influenced mainly by the relative dominance $(\mathrm{ReDo}=32.07 \%)$. C. benghalensis was present in areas B2, B3 and B4 and the relative density was the parameter that most contributed to elevate the IVI of this species (Figure 1B). This indicates that these species were favored by weeding carried out after samplings in the vegetative phase and can be considered as having great potential to cause damages to the crop.

In the Brazilian municipality of Alto Alegre do Pindaré, during the vegetative phase of the rice crop the main weeds were $C$. flavus in areas P1 (IVI $=72.94 \%)$ and P3 (IVI $=90.35 \%)$ and C. argutus in areas P2 (IVI $=95.49 \%$ ) and P4 (IVI $=71.31 \%$ ) (Figure 2A). This shows this species adaptation level to the cultivation conditions and its potential to interfere in cultural practices and reduction of upland rice cultivation yield in the humid tropics. Marques et al. (2011) have also identified these species as having significant importance in the weed community of cowpea in a cutting and burning system - food culture of great relevance for family farmers who grow it at the end of the rainy season. 

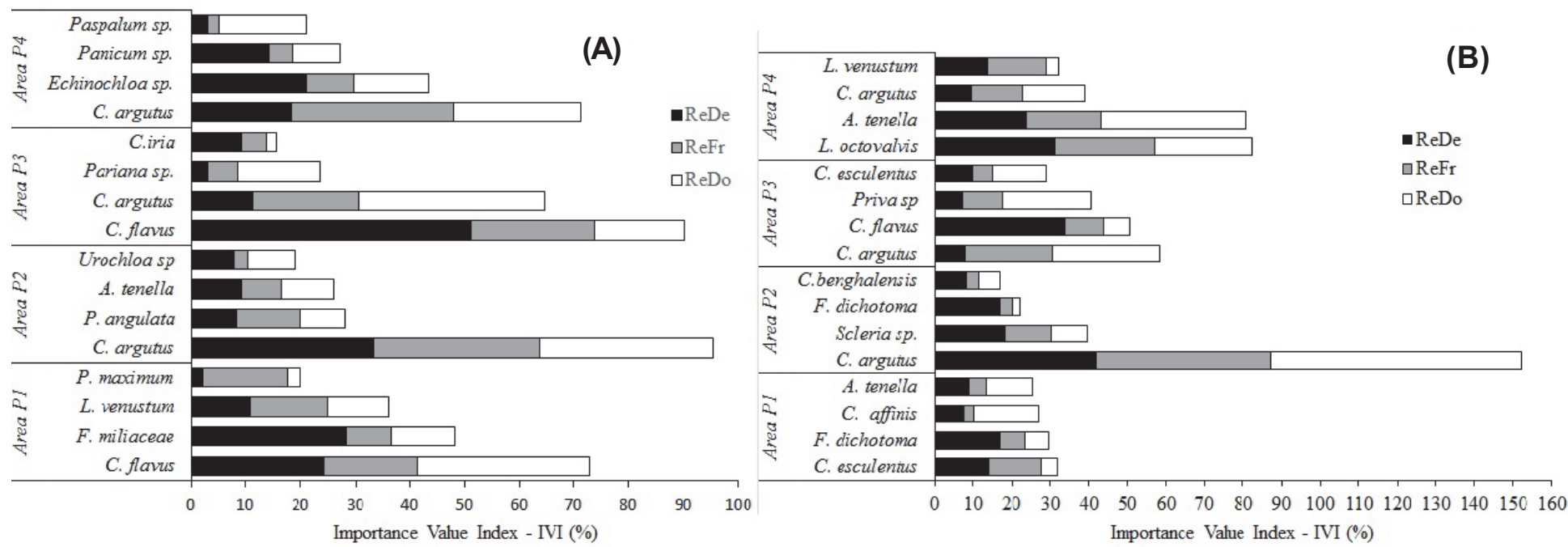

Figure 2 - Phytosociological parameters of the main weeds in (A) vegetative and (B) reproductive phases of upland rice cultivation in the Brazilian municipality of Alto Alegre do Pindaré, MA. 2010/2011.

In the rice crop reproductive phase in Alto Alegre do Pindaré there was also some change in predominance of the species in most areas. In area P1, C. esculentus had the greatest importance $(\mathrm{IVI}=31.80 \%)$, followed by $F$. dichotoma $(\mathrm{IVI}=29.66 \%)$. In area P3 it was $C$. argutus (IVI $=58.41 \%)$ and $C$. flavus (IVI $=50.62 \%$ ). And in area P4, L. octovalvis and A. tenella, with IVIs of $82.43 \%$ and $80.82 \%$, respectively. Only in area P2 C. argutus kept and increased its importance (IVI $=152 \%)$ in the weed community, where relative dominance $(\mathrm{ReDo}=64.74 \%)$ was the main variable (Figure 2B). This indicates the need to control this species from the vegetative stage, because, besides high density, it presents rapid absorption and accumulation of nutrients. According to Pitelli (2000), the species that obtain the largest accumulations of dry matter influence, to a greater degree, the weed community behavior.

Species $C$. esculentus and $F$. dichotoma in area P1 were significant in the weed community due to their relative densities, which corresponded to $14.14 \%$ and $16.75 \%$, respectively (Figure 2B). These weeds belong to the Cyperaceae family and are problematic in rice cultivation in wetlands. Erasmo et al. (2003) have observed some reduction in rice yield of around $20.11 \%$ for the density of 200 C. esculentus plants, representing, on average, a loss of 17 bushels ha ${ }^{-1}$. As for Silva et al. (2014), they have evidenced some high density of $F$. dichotoma in the rice cultivation seed bank in the municipality mentioned.

The importance of $L$. octovalvis in the crop reproductive phase was mainly associated with its relative density $(\mathrm{ReDe}=31.13 \%)$, which expresses the high number of individuals in the weed community (Figure 2B). It is a species of the Onagraceae family that propagates by seeds, probably with the widest geographical distribution in Brazil. It infests in wet or flooded areas, including rice floodplain fields (Kissmann and Groth, 2000). Mesquita et al. (2013), evaluating the weeds seed bank in rice crop in a cutting and burning system of the vegetation, have verified the occurrence of this species with great plasticity, that is, capacity to adapt to different locations, as well as tolerance to human activities and stress conditions imposed by environmental factors.

The species A. tenella, besides the high IVI value in the P4 area, was also relevant in the P1 area. In both areas, relative dominance was the main parameter, with values of $37.52 \%$ and $11.87 \%$, respectively (Figure 2B). This species is a late emergence weed in agricultural crops and of relevance in upland rice cultivation. Studies by Silva and Durigan (2006) evaluating weed interference in upland rice cultivations have verified its dominance from the $30 \mathrm{DAE}$ to the harvest when it surpassed the other species due to accumulations of dry matter.

Regarding species diversity (H') in the municipality of Buriticupu, it has ranged between 0.97 and 2,12 in the vegetative phase and from 1.67 to 2.61 in the reproductive one. In Alto Alegre do Pindaré, variation in the vegetative phase was from 1.86 to 2.42. And in the reproductive one it was from 1.74 to 2.64 (Table 2). This means that in the municipalities the species diversity 
was higher in the reproductive phase than in the vegetative phase. And that the greatest species diversity occurred in Alto Alegre do Pindaré, probably due to two areas subject to flooding, which provided more favorable conditions for weeds, and/or the larger sample area relative to Buriticupu. Similar values for floristic diversity were obtained by Mesquita et al. (2013) and Silva et al. (2014) in upland rice cultivation in the cutting and burning system in areas located in the humid tropic region of the Brazilian state of Maranhão.

Table 2 - Shannon's diversity index for a weed community in the vegetative and reproductive phases of upland rice cultivation in Brazilian municipalities Buriticupu and Alto Alegre do Pindaré, MA, 2009/2010 and 2010/2011, respectivamente

\begin{tabular}{|c|c|c|c|c|c|}
\hline \multicolumn{2}{|c|}{ Diversity index } \\
\hline \multirow{2}{*}{ Areas } & \multicolumn{2}{|c|}{ Buriticupu } & \multirow{2}{*}{ Areas } & \multicolumn{2}{c|}{ Alto Alegre do Pindaré } \\
\cline { 2 - 3 } & Vegetative phase & Reproductive phase & & Vegetative phase & Reproductive phase \\
\hline B1 & 2.12 & 2.12 & P1 & 2.23 & 2.64 \\
\hline B2 & 1.19 & 2.07 & P2 & 2.32 & 1.74 \\
\hline B3 & 0.97 & 1.67 & P3 & 1.86 & 2.07 \\
\hline B4 & 2.01 & 2.61 & P4 & 2.42 & 1.89 \\
\hline
\end{tabular}

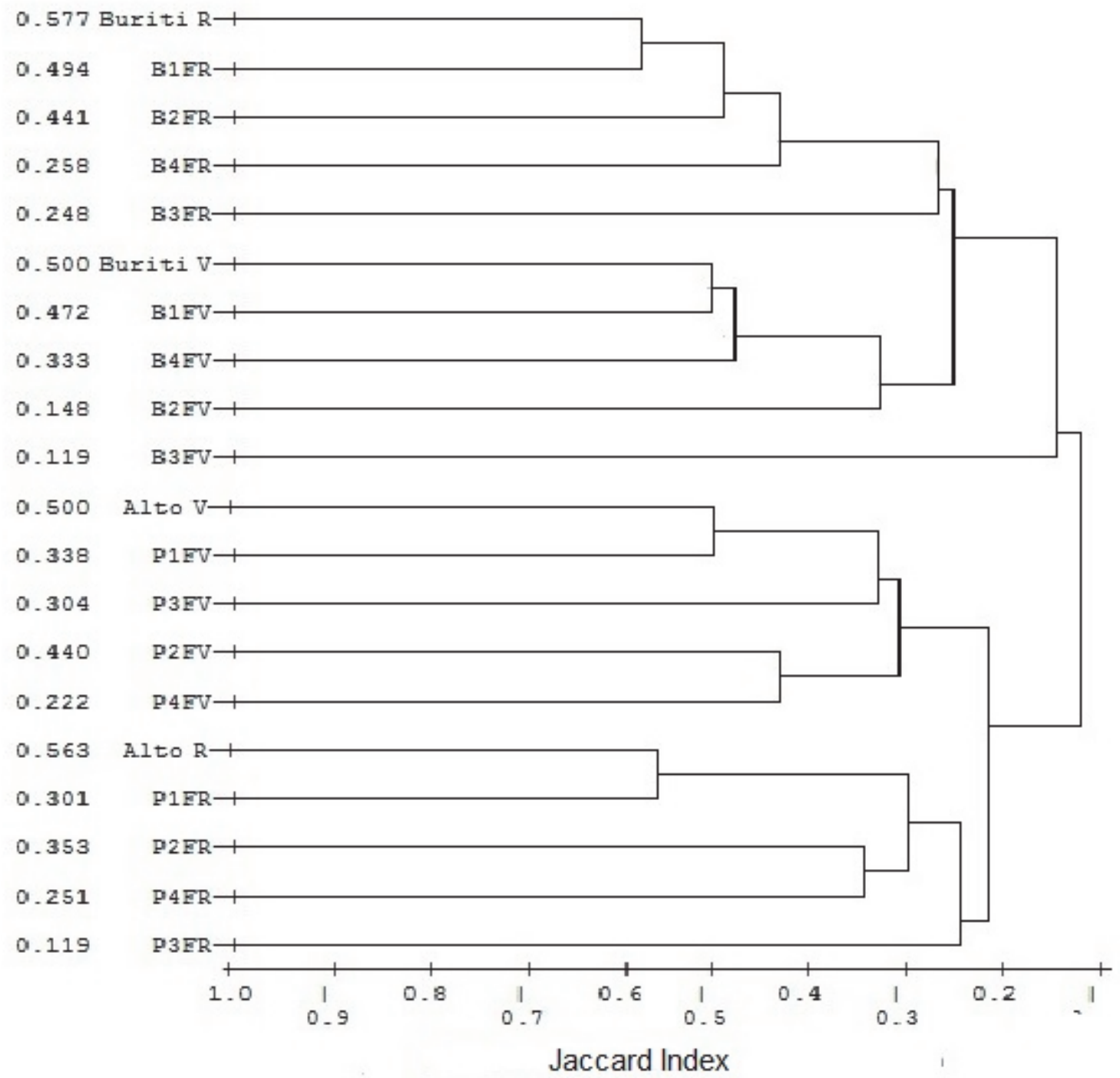

Figure 3 - Dendrogram of floristic similarity of a weed community in the vegetative and reproductive phases of upland rice cultivation among the Brazilian municipalities of Buriticupu and Alto Alegre do Pindaré, MA, 2009/2010 and 2010/2011, respectively. 
The floristic similarity among weed communities was higher in the crop reproductive phase, with the highest value observed in the municipality of Buriticupu in the B1 area, followed by the P1 area in Alto Alegre do Pindaré. Between the two municipalities floristic similarity was low (Figure 3). This shows the difference in the floristic composition of the weed community between the crop vegetative and reproductive phases that was observed in the analysis of the phytosociological indexes and the need to perform some differentiated management for the municipalities mentioned. Silva et al. (2014) have not observed floristic similarity among weed communities of upland rice cultivation either between the municipalities of Alto Alegre do Pindaré and Santa Luzia, located in this micro-region under study.

For upland rice cultivation in the humid tropics, species diversity was high and floristic composition changed between the crop vegetative and reproductive phases, with greater similarity in the latter. The most important weeds in the crop vegetative phase were mainly of the monocotyledonous class (Urochloa sp., Panicum sp., C. benghalensis, C. flavus and C. argutus), while in the reproductive system eudicotyledons predominated (S. latifolia, P. maximum, C. argutus, L. octovalvis and A. tenella). The families with the highest species richness were Poaceae and Cyperaceae, followed by Amaranthaceae and Malvaceae, and floristic similarity between the municipalities was low.

\section{ACKNOWLEDGMENTS}

To Brazilian Banco do Nordeste S/A (BNB), which has financially contributed to the realization of this research, and to Brazilian Fundação de Amparo à Pesquisa e ao Desenvolvimento Científico e Tecnológico do Maranhão - FAPEMA, for the Scientific Initiation Grant.

\section{REFERENCES}

Companhia Nacional de Abastecimento - Conab. Acompanhamento da Safra Brasileira de Grãos. v.2 n. 11 - $12^{\circ}$ Levantamento Setembro 2015. [acesso 24 de abr. de 2016]. Disponível em: http://www.conab.gov.br/OlalaCMS/uploads/arquivos/ 15_09_11_10_42_03_boletim_graos_setembro_2015.pdf

Cobucci T., Rabelo R.R., Silva W. Manejo de plantas daninhas na cultura do arroz de terras altas na região dos Cerrados. Santo Antônio de Goiás: Embrapa Arroz e Feijão, 2001. 60p. (Circular técnica, 42).

Erasmo E.A.L. et al. Efeito da densidade e dos períodos de convivência de Cyperus esculentus na cultura do arroz irrigado. Planta Daninha. 2003;21:381-6.

Gerência de Planejamento e Desenvolvimento Econômico - GEPLAN. Atlas do Maranhão. São Luís: Laboratório de Geoprocessamento-UEMA, 2002. 32 p.

Kissmann K.G., Groth D. Plantas infestantes e nocivas. 2a . ed. São Paulo: BASF, 2000. Tomo III. 726 p.

Kuva M.A. et al. Períodos de interferência das plantas daninhas na cultura da cana-de-açúcar. III - capim-braquiária (Brachiaria decumbens) e capim-colonião (Panicum maximum). Planta Daninha. 2003;21:37-44.

Magurran A.E. Ecological diversity and its measurement. Londres: Princeton University Press, 1988. 192 p

Marques L.J.P. et al. Dinâmica de populações e fitossociologia de plantas daninhas no cultivo do feijão-caupi e mandioca no sistema corte e queima com o uso de arado. Planta Daninha. 2011;29:981-9. (Número Especial).

Mesquita M.L.R., Andrade L.A., Pereira W.E. Floristic diversity of the soil weed seed bank in a rice-growing area of Brazil: in situ and ex situ evaluation. Acta Bot Bras. 2013;27:465-71.

Mesquita M.L.R., Andrade L.A., Pereira W.E. Banco de sementes do solo em áreas de cultivo de subsistência na Floresta Ombrófila Aberta com Babaçu (Orbygnia phalerata Mart.) no Maranhão. Revista Árvore. 2014;38:677-88.

Müeller-Dombois D., Ellemberg H. Aims and methods of vegetation ecology. New York: Willey, 1974. 547 p.

Penckowski L.H., Rocha D.C. Guia ilustrado de identificação e controle de espécies de trapoerabas. Castro: Fundação ABC, 2006. 50 p. 
Pinto Coelho R.M. Fundamentos em ecologia. Porto Alegre: Artes Médicas Sul, 2000. 252 p.

Pitelli R.A. Estudos fitossociológicos em comunidades infestantes de agroecossistemas. J Consherb. 2000;1:1-7.

Santos H.G. et al. Sistema brasileiro de classificação de solos. $3^{\mathrm{a}}$ ed. rev. ampl. Brasília, DF: Embrapa, 2013. 353 p.

Shepherd G.J. FITOPAC 1: manual do usuário. Campinas: UNMICAMP/Departamento de Botânica, 1994. 93 p.

Silva M.R.M., Durigan J.C. Períodos de interferência das plantas daninhas na cultura do arroz de terras altas. I - cultivar iac 202. Planta Daninha. 2006;24:685-94.

Silva M.R.M., Durigan J.C. Períodos de interferência das plantas daninhas na cultura do arroz de terras altas. II - cultivar caiapó. Bragantia. 2009;68:373-9.

Silva M.R.M. et al. Cadastramento fitossociológico de plantas daninhas na cultura do arroz de terras altas no município de Santa Luzia - MA. Rev Cienc. Agroamb. 2013;11:51-60.

Silva M.R.M. et al. Phytosociology and interference of weeds in upland rice in Maranhão State, northeastern Brazil. Afr J Agric Res. 2015;10:3412-20.

Terra T.G.R. et al. Comunidade infestante sob duas condições de irrigação na cultura do arroz de sequeiro. J Biotecnol Biodiv. 2012;3:199-205.

Touré A., Sogbedji J.M., Gumedzoé Y.M.D. The critical period of weed interference in upland rice in Northern Guinea Savana: Field measurement and model predicition. Afr J Agric Res. 2013;8:1748-59. 